\title{
E, SEM TALENTO, FAÇO UM TRABALHO TÉCNICO, VIOLENTO"
}

\author{
Marco Catalão
}

A concepção romântica do escritor "inspirado" parece estar completamente desacreditada no debate contemporâneo sobre a criação literária. Enquanto, no início do século XX, Rilke ainda declarava ter ouvido do vento as primeiras palavras das Elegias de Duíno e Manuel Bandeira afirmava que "não forçava a mão" ao compor um poema, hoje a inspiração só aparece no discurso dos escritores como coadjuvante no clichê que afirma que a "transpiração" é o elemento decisivo para a criação literária. "Não há inspiração, há trabalho", afirma José Saramago numa entrevista recente; "a poesia é fruto do trabalho paciente e lúcido do poeta”, já asseverava João Cabral há cinquenta anos.

No entanto, há uma série de práticas que continuam a afirmar (implícita ou explicitamente) a atividade do escritor como radicalmente distinta da de outros profissionais mais "prosaicos", como o professor ou o cientista. A desconfiança em relação à ideia mítica da "inspiração" deu lugar não a uma concepção mais realista da escrita artística, mas a outro conceito cujo campo semântico está inelutavelmente associado à esfera religiosa: o de "talento". Mesmo entre os que consideram que a escrita é um "trabalho como qualquer outro", ainda predomina a concepção de que esse trabalho está reservado a poucos indivíduos dotados de um dom natural e intransferível, que pode até ser explicado em termos supostamente científicos (como predisposição genética ou capacidade cognitiva), mas que estabelece uma cisão radical entre os "talentosos" e os "medíocres", os "criativos" e os "prosaicos". 
Não me dedicarei aqui a demonstrar a falácia dessa concepção, uma vez que tal tarefa demandaria um tempo superior àquele de que disponho. Fique apenas a sugestão para que se investigue o processo criativo dos escritores relevantes de qualquer época ou lugar - e não só dos escritores, mas de qualquer artista - a fim de se comprovar que nenhum talento inato jamais foi capaz de fazer surgir qualquer obra de arte importante sem um longo processo de aprendizado e de luta com a matéria artística. Meu objetivo neste breve depoimento é investigar as consequências danosas do conceito de "talento" tanto no âmbito da criação literária quanto no ensino de literatura.

Tomemos como ponto de partida um indivíduo que deseje criar uma obra literária - ou, mais radicalmente, um indivíduo que se interesse pela literatura a ponto de querer dedicar sua vida a ela - não como crítico literário ou professor, mas como escritor. Não estou falando aqui de nenhuma vocação mística, mas apenas do mesmo desejo ou necessidade que leva alguém a querer dedicar sua vida à medicina, à engenharia, à culinária ou ao futebol. Se a concepção da literatura como trabalho e prática concreta estivesse minimamente difundida em nossa sociedade, esse indivíduo encontraria condições mínimas para exercer seu trabalho.

Não é isso, contudo, o que acontece. Ao contrário dos profissionais mais "prosaicos", que podem enunciar impunemente seu desejo de serem jornalistas, professores, motoristas e até mesmo deputados, aqueles que se aventuram a afirmar que querem ser escritores são obrigados a se confrontar com uma pergunta aterradora: "Mas você tem talento para isso?". Foi exatamente essa a pergunta que eu ouvi de um professor desta mesma universidade no momento em que eu, com toda a ingenuidade dos meus vinte e poucos anos, lhe disse que queria "só" escrever. E esse professor não era nenhum tolo que ignorasse os debates contemporâneos sobre a criação literária; ao contrário, era um intelectual que eu respeitava e que ainda respeito e estimo.

Eu me vi então diante de um impasse aparentemente insolúvel: eu me conhecia muito bem para saber que não tinha nem um pingo de talento, e já conhecia o suficiente de literatura para saber que eu nunca conseguiria chegar ao nível de um Drummond, para não falar de um Fernando Pessoa; mas ao mesmo tempo eu sabia que nenhum trabalho me daria a plenitude que sentia ao escrever - ainda que nada do que eu escrevesse tivesse qualquer mérito transcendental. Nesse contexto, a opção mais razoável seria me dedicar a um trabalho supostamente mais sério e deixar a literatura para os talentosos — limitando-me a escrever uma ou outra página nas horas de folga ou nos fins de semana. 
Se eu conto essa anedota aqui, é porque ela ilustra uma das consequências mais funestas da teoria do "talento": a ideia (firmemente arraigada no senso comum e, como vimos, também no meio acadêmico) de que a prática da literatura - e da arte de um modo geral — está reservada apenas a pessoas especiais, raras e particularmente criativas, enquanto as pessoas "normais" devem se contentar com o papel de meros consumidores. Um dos desdobramentos dessa concepção é que aqueles com maior autocrítica serão os primeiros a reconhecer seu escasso talento - e, consequentemente, a abandonar a prática da escrita, deixando-a para as centenas de "gênios incompreendidos" que não têm qualquer dúvida sobre o próprio valor.

Voltando ao hipotético aspirante a escritor de que eu falava anteriormente, ainda que ele vença esse primeiro obstáculo e declare a si mesmo que tem talento (ou, como foi o meu caso, que não tem talento, mas que a sua vontade de escrever é tão grande que supera a própria falta de talento), como ele poderá exercer seu trabalho? Ao contrário do que ocorre na maioria das outras profissões, não bastarão dez ou doze horas diárias de trabalho; tampouco será suficiente escrever uma obra-prima a cada dois ou três anos (o que já estaria muito acima da média dos maiores escritores dos últimos séculos); para que um escritor sobreviva "apenas" escrevendo, ele precisa escrever obras "vendáveis": livros que vendam no mínimo seis mil exemplares por ano (isso se ele se contentar com uma vida frugal e se o seu editor for honesto e lhe repassar integralmente os $10 \%$ do valor de capa).

Em outras palavras, o único talento que realmente pode dar segurança econômica a um escritor é o talento mercadológico, que pode se ramificar em dezenas de outros subtalentos: o talento para fazer amizades com donos de editoras e jornalistas influentes, o talento para dar entrevistas falsamente polêmicas, o talento para a autopromoção nas redes sociais, $o$ talento para se transformar em imagem consumível pelo "grande público". Desnecessário dizer que todos esses subtalentos estão em contradição com o único requisito indispensável a todo artista digno desse nome: a coragem de praticar sua arte até as últimas consequências.

Restam então duas opções ao escritor que não aceita ser apenas mais um produto da indústria editorial: aceitar a indigência como destino ou arranjar outro meio de sustento, reservando à escrita não as horas mais férteis e intensas do dia, mas as que porventura sobrarem do "verdadeiro trabalho". O fato de haver tantos escritores professores, escritores jornalistas, escritores advogados e escritores diplomatas e tão poucos escritores "apenas" escritores evidencia de forma cristalina o valor conferido pela nossa sociedade à atividade literária: por mais que se fale 
em trabalho e "transpiração", espera-se que os escritores criem obrasprimas num rompante de talento, talvez parados no trânsito a caminho do trabalho, e não num processo longo, que demanda as melhores horas do dia e toda a sua energia criativa.

Se um escritor se define pelo talento inato e não pelo trabalho cotidiano, o máximo a que um jovem escritor pode aspirar é o "reconhecimento": entrar para o clube seleto dos que têm permissão para se intitular de escritores. A profusão de prêmios literários, em contraposição à escassez de bolsas ou programas continuados de formação técnica, é outro elemento que confirma o pressuposto que rege as atividades ligadas à criação literária no país: identificado o talento, espera-se que a obraprima seja uma consequência natural e inevitável.

O mesmo pressuposto equivocado norteia o ensino de literatura no país: desde os primeiros anos de escola, o aluno é incitado a assumir seu lugar de receptor (ou mais cruamente: de consumidor) de obras literárias supostamente criadas por "grandes autores" numa linguagem hipoteticamente "mais elevada" que a falada por ele. As obras literárias são vistas como produtos acabados, e praticamente não há lugar nas aulas de literatura para o processo de criação, com seus altos e baixos, dúvidas e incertezas.

Sob essa perspectiva, não é de se estranhar que os alunos demonstrem pouco interesse pela literatura: ao mesmo tempo em que percebem sua irrelevância na sociedade contemporânea, veem-se induzidos a admirála "de baixo para cima", com a reverência supersticiosa que se dedica aos grandes desconhecidos. Uma vez que os livros já estão autenticados de antemão pelo selo de qualidade do "talento", a leitura não pode ser uma atividade crítica, inventiva e surpreendente: é apenas a recepção passiva de um produto acabado e irrepreensível.

Assim, o conceito de "talento" não forma apenas escritores medíocres, mas também leitores inconsistentes e desinteressados. E os maiores interessados na existência de leitores qualificados são os próprios escritores (não os gênios que só esperam pelos louros da glória, mas os escritores prosaicos, que tentam, erram e voltam a tentar): sem o retorno crítico de leitores autênticos, eles estarão condenados a escrever para si mesmos, fechados numa atividade socialmente inócua.

Não se trata de reivindicar uma situação mais fácil ou confortável para os escritores. Ao contrário: é justamente por considerar o ato de escrever terrivelmente difícil e exigente que eu insisto na necessidade da dedicação plena e exclusiva do escritor ao ofício literário. Ao contrário do sucesso editorial ou do reconhecimento público - que não é fácil nem difícil, mas um tanto quanto casual e arbitrário - a criação de uma obra relevante 
requer muito mais que talento ou sorte: requer uma quantidade de esforço significativo que não é menor do que a requerida para se formular uma nova teoria científica ou uma descoberta tecnológica inovadora.

Da mesma forma que a ciência só se desenvolveu vertiginosamente a partir do momento em que deixou de ser exercida por um ou outro indivíduo particularmente talentoso (e com tempo e dinheiro suficientes para desenvolver o seu talento ao longo de vários anos) e passou a ser incentivada por políticas públicas que garantiam aos pesquisadores a possibilidade de se dedicarem a experiências e investigações livres da tutela do mercado, a literatura (assim como a arte em geral) só sairá do seu estado anacrônico de amadorismo a partir do momento em que os escritores tiverem liberdade para criar suas obras com a integridade exigida pela arte. 